\title{
STUDIES ON NEW ANTIBIOTICS SF2415 \\ I. TAXONOMY, FERMENTATION, ISOLATION, PHYSICO-CHEMICAL PROPERTIES AND BIOLOGICAL ACTIVITIES
}

\author{
Гakashi Shomura, Shuichi Gomi, Mitsugu Ito, Junko Yoshida, \\ Eriko Tanaka, Shoichi Amano, Hiro-omi Watabe, \\ Shokichi OHUchi, Jiko ITOH and Masaji Sezaki \\ Pharmaceutical Research Laboratories, Meiji Seika Kaisha, Ltd., \\ Morooka-cho, Kohoku-ku, Yokohama 222, Japan \\ HideHI TAKeBE and KaZUMTCHI UOTANI \\ Pharmaceutical Development Laboratories, Meiji Seika Kaisha, Ltd., \\ Horikawa-cho, Saiwai-ku, Kawasaki 210, Japan \\ (Received for publication January 9, 1987)
}

\begin{abstract}
A new species of Streptomyces is described for which the name Streptomyces aculeolatus is proposed. The organism produces new antibiotics SF2415A1, A2, A3, B1, B2 and B3 active against Gram-positive bacteria. Empirical molecular formulae of the antibiotics $\mathrm{SF} 2415 \mathrm{~A} 1, \mathrm{~A} 2, \mathrm{~A} 3, \mathrm{~B} 1, \mathrm{~B} 2$ and $\mathrm{B} 3$ were determined to be $\mathrm{C}_{26} \mathrm{H}_{31} \mathrm{~N}_{2} \mathrm{O}_{5} \mathrm{Cl}, \mathrm{C}_{28} \mathrm{H}_{30} \mathrm{~N}_{2} \mathrm{O}_{5}$, $\mathrm{C}_{26} \mathrm{H}_{30} \mathrm{~N}_{2} \mathrm{O}_{5} \mathrm{Cl}_{2}, \mathrm{C}_{26} \mathrm{H}_{33} \mathrm{O}_{5} \mathrm{Cl}, \mathrm{C}_{26} \mathrm{H}_{32} \mathrm{O}_{5}$ and $\mathrm{C}_{26} \mathrm{H}_{32} \mathrm{O}_{5} \mathrm{Cl}_{2}$, respectively.
\end{abstract}

In the course of our screening program for new antibiotics, we have isolated a strain of Streptomyces, designated strain SF2415, which produces new antibiotics SF2415.

In this paper, we report the taxonomy of the producing organism, fermentation, isolation, physicochemical properties and biological activities of the antibiotics SF2415. The structural elucidation of the antibiotics SF2415 is described in accompanying paper. ${ }^{1)}$

\section{Materials and Methods}

Taxonomic Studies of Antibiotics Producing Strain

The producing organism, strain SF2415, was isolated from a soil sample collected in Tottori Prefecture, Japan.

Methods adopted by the International Streptomyces Project (ISP) ${ }^{2)}$ were used for taxonomic characterization and carbohydrate utilization studies. Cultural characteristics were determined on media recommended by the ISP and WAKSMAN. ${ }^{32}$ Observations were made after incubation at $28^{\circ} \mathrm{C}$ for 14 days.

The procedure of BECKER et al..$^{4)}$ was used for the preparation of cells and chromatographic detection of the isomers of diamino-pimeric acid.

Fermentation of Streptomyces aculeolatus

A slant culture of strain SF2415 was inoculated into a 100-ml Erlenmeyer flask that contained $20 \mathrm{ml}$ of a seed medium consisting of starch $2 \%$, glucose $1 \%$, wheat germ $0.6 \%$, Polypeptone $0.5 \%$, yeast extract $0.3 \%$, soybean meal $0.2 \%$ and $\mathrm{CaCO}_{3} 0.1 \%$ (pH 7). The inoculated flask was cultured on a rotary shaker $(220 \mathrm{rpm})$ at $28^{\circ} \mathrm{C}$ for 3 days. The first seed culture $(4 \mathrm{ml})$ was inoculated into $80 \mathrm{ml}$ of the same medium in a $500-\mathrm{ml}$ Erlenmeyer flask. After shaking at $28^{\circ} \mathrm{C}$ for 2 days, the second seed culture was obtained. The second seed $(50 \mathrm{ml})$ was added to a 5 -liter Erlenmeyer flask containing 1 liter of the same medium. The third seed culture was shaken at $28^{\circ} \mathrm{C}$ for 24 hours, and 1 liter of 
the culture was added to a 50-liter jar fermentor containing 35 liters of the production medium (starch $2 \%$, soybean oil $1 \%$, cotton seed meal $1.5 \%$, corn gluten meal $0.7 \%, \mathrm{CaCO}_{3} 0.3 \%$ and $\mathrm{FeSO}_{4} \cdot 7 \mathrm{H}_{2} \mathrm{O}$ $0.001 \%$ in a tap water ( $\mathrm{pH} 7$ before sterilization)).

Fermentation was carried out at $28^{\circ} \mathrm{C}$ for 72 hours with an air-flow rate of 20 liters per minute, and an agitation rate of $250 \mathrm{rpm}$ for first 41 hours and $400 \mathrm{rpm}$ for the remaining course of the fermentation. Packed cell volumes were determined by centrifuging at $3,000 \mathrm{rpm}$ for 15 minutes in $15 \mathrm{ml}$, conical tubes. Antibiotic activity was determined by a paper-disc agar diffusion assay, using Micrococcus luteus PCI 1001 as an assay organism. Antibiotic SF2415A1 was used as an assay standard.

\section{Isolation of Antibiotics SF2415}

The fermentation broth in a 50 -liter jar fermentor was filtered by using Hyflo Super-Cel (JohnsManville) as the filter aid and the filtrate ( 30 liters) and packed cells (10 liters) were obtained. The antibiotics in the packed cells were extracted with a mixture $(1: 1,30$ liters $)$ of $\mathrm{Me}_{2} \mathrm{CO}$ and water and the extract was concd to 10 liters. The antibiotics in the filtrate were adsorbed on a column of Diaion HP-20 (3 liters) and the antibiotics were eluted with a mixture $\left(1: 1,30\right.$ liters) of $0.5 \mathrm{~N} \mathrm{NH}_{4} \mathrm{OH}$ and $\mathrm{Me}_{2} \mathrm{CO}$. The active eluates were collected and concd to 5 liters. Concentrated extracts and eluates were combined and the antibiotics in the mixture extracted with EtOAc (15 liters). The resulting extract was then concd under reduced pressure to give a dark red oil $(38 \mathrm{~g})$. The residual oil was adsorbed on $50 \mathrm{~g}$ of silica gel and charged on a silica gel column $(200 \mathrm{~g})$. The column was eluted stepwise with toluene - EtOAc $(75: 1,300 \mathrm{ml}),(50: 1,340 \mathrm{ml}),(20: 1,1,000 \mathrm{ml})$ and $(10: 1,1,100 \mathrm{ml})$. Approximately $170-\mathrm{ml}$ fractions were collected. The fractions (Nos. 3 5) containing SF2415B2 (B2) were concd to give a brownish oil $(1.26 \mathrm{~g})$ and further purification was achieved by column chromatography on silica gel $(150 \mathrm{~g})$ eluting with toluene - EtOAc $(20: 1)$ to afford a yellow oil (180 $\mathrm{mg}$ ) of B2. The fractions (Nos. 6 7) containing SF2415B1 (B1) and SF2415B3 (B3) were concd to give a brownish oil $(1.09 \mathrm{~g})$. The crude oil was further purified by Sephadex LH-20 (800 ml) chromatography developed with a mixture $(9: 1)$ of $\mathrm{CHCl}_{3}$ and $\mathrm{MeOH}$ followed by column chromatography on silica gel $(50 \mathrm{~g})$ eluted with toluene - EtOAc $(75: 1)$ to give a pale yellow oil $(280 \mathrm{mg})$ of B1 and hygroscopic yellow needles $(250 \mathrm{mg}$ ) of B3. The fractions (Nos. 9 11) on the first silica gel column chromatography containing SF2415A2 (A2) and SF2415A3 (A3) were concd to give a dark red oil $(1.16 \mathrm{~g})$. The residual oil was purified by chromatography on Sephadex LH-20 $(800 \mathrm{ml})$ developed with a mixture $(9: 1)$ of $\mathrm{CHCl}_{3}$ and $\mathrm{MeOH}$ to give a crude oil $(470 \mathrm{mg})$. The crude oil was further purified by column chromatography on silica gel $(40 \mathrm{~g})$ eluted with toluene - EtOAc $(75: 1)$ and $(50: 1)$ followed by preparative TLC developed with hexane $-\mathrm{Me}_{2} \mathrm{CO}(3: 1)$ to afford a red oil $(54 \mathrm{mg})$ of A2 and a hygroscopic red powder $(50 \mathrm{mg})$ of A3. The fractions (Nos. 13 15) on the first silica gel column chromatography containing SF2415A1 (A1) was concd to give a dark orange oil $(1.14 \mathrm{~g})$ and was further purified by Sephadex LH-20 $(800 \mathrm{ml})$ chromatography developed with a mixture $(9: 1)$ of $\mathrm{CHCl}_{3}$ and $\mathrm{MeOH}$ followed by chromatography on silica gel $(30 \mathrm{~g})$ eluted with toluene - EtOAc $(10: 1)$ to afford an orange powder $(132 \mathrm{mg})$, which was recrystallized from hexane to give $70 \mathrm{mg}$ of yellow needles of $\mathrm{A} 1$.

\section{Results and Discussion}

\section{Taxonomy of Strain SF2415}

Vegetative mycelium was well developed and branched. The hyphae did not fragment into coccoid or bacillary elements. Aerial mycelium was simply branched and terminated in open or closed coils. Mature spore chains have 10 or more spores per chain. This morphology was observed in sucrose - nitrate agar, glycerol - asparagine agar (ISP medium 5), and inorganic salts - starch agar (ISP medium 4). Spores were ellipsoidal in shape, $0.8 \sim 1.2$ by $1.0 \sim 1.6 \mu \mathrm{m}$ in size. Surface irregularities on spores were intermediate between warts and spines (Figs. 1 and 2). Sporangia, flagellated spores, and sclerotic granules were not observed.

Cultural characteristics of strain SF2415 are shown in Table 1. Aerial mass color was in the 
Fig. 1. Transmission electron micrograph of a spore chain of strain SF2415 on inorganic salts - starch agar (ISP medium 4) incubated at $28^{\circ} \mathrm{C}$ for 14 days. $\times 20,000$.

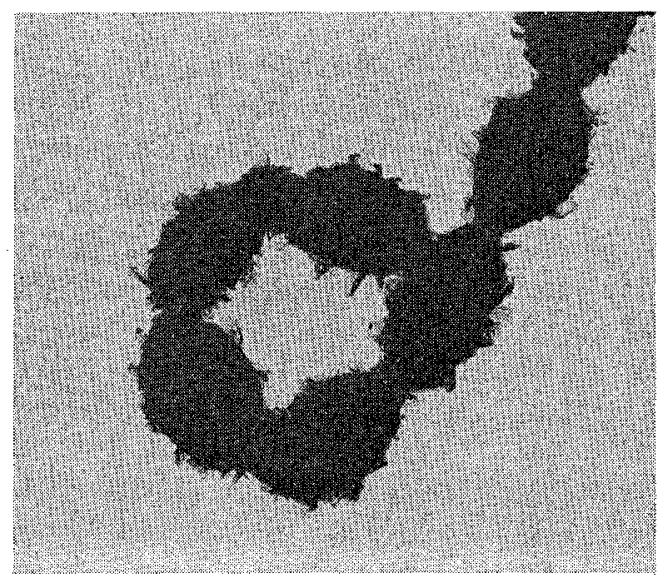

Fig. 2. Scanning electron micrograph of a spore chain of strain SF2415 on glycerol - asparagine agar (ISP medium 5) incubated at $28^{\circ} \mathrm{C}$ for 14 days. $\times 15,000$.

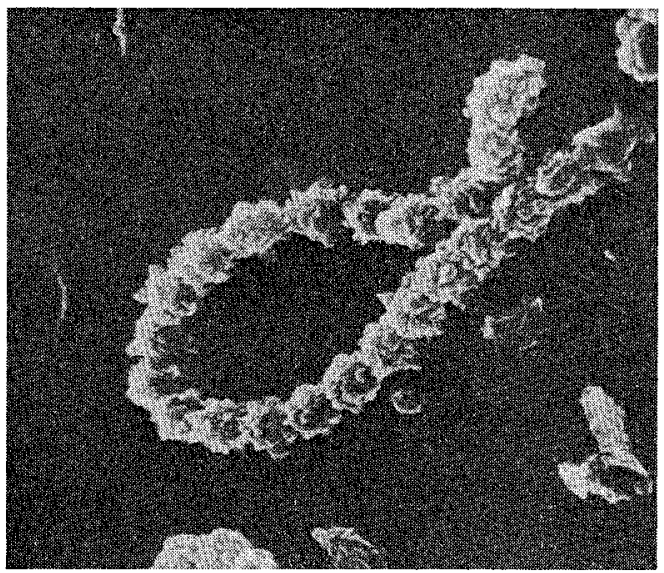

Table 1. Cultural characteristics of strain SF2415.

\begin{tabular}{|c|c|c|c|c|}
\hline Medium & Growth & $\begin{array}{c}\text { Aerial } \\
\text { mycelium }\end{array}$ & Reverse* & $\begin{array}{l}\text { Soluble } \\
\text { pigment }\end{array}$ \\
\hline Sucrose - nitrate agar & $\begin{array}{l}\text { Poor to } \\
\text { moderate }\end{array}$ & White (a) & $\begin{array}{l}\text { Colorless to light } \\
\text { yellow (1ea) }\end{array}$ & None \\
\hline $\begin{array}{l}\text { Glucose - asparagine } \\
\text { agar }\end{array}$ & Poor & None & Colorless & None \\
\hline $\begin{array}{l}\text { Glycerol - asparagine } \\
\text { agar } \\
\text { (ISP medium 5) }\end{array}$ & Moderate & White (a) & $\begin{array}{l}\text { Colorless to light } \\
\text { yellow (1ea) }\end{array}$ & None \\
\hline $\begin{array}{l}\text { Inorganic salts - } \\
\text { starch agar } \\
\text { (ISP medium 4) }\end{array}$ & $\begin{array}{l}\text { Moderate } \\
\text { to good }\end{array}$ & $\begin{array}{l}\text { White (a) } \\
\text { to shell (3ca) }\end{array}$ & $\begin{array}{l}\text { Light melon yellow } \\
\text { (3ea) }\end{array}$ & $\begin{array}{l}\text { Light } \\
\text { apricot }\end{array}$ \\
\hline $\begin{array}{l}\text { Calcium - malate } \\
\text { agar }\end{array}$ & $\begin{array}{l}\text { Poor to } \\
\text { moderate }\end{array}$ & $\begin{array}{l}\text { White (a) } \\
\text { to ivory }(2 \mathrm{db})\end{array}$ & Maple (4le) & $\begin{array}{l}\text { None, or } \\
\text { pale brown }\end{array}$ \\
\hline $\begin{array}{l}\text { Oatmeal agar } \\
\text { (ISP medium 3) }\end{array}$ & $\begin{array}{l}\text { Poor to } \\
\text { moderate }\end{array}$ & $\begin{array}{l}\text { Scant, } \\
\text { white (a) }\end{array}$ & Orange (4la) & None \\
\hline $\begin{array}{l}\text { Yeast extract - malt } \\
\text { extract agar } \\
\text { (ISP medium 2) }\end{array}$ & Good & $\begin{array}{l}\text { None, or } \\
\text { scant, ivory } \\
\text { (2db) }\end{array}$ & $\begin{array}{l}\text { Maple (4le) to dusty } \\
\text { orange (4le) }\end{array}$ & $\begin{array}{l}\text { Pale } \\
\text { brownish } \\
\text { orange }\end{array}$ \\
\hline $\begin{array}{l}\text { Tyrosine agar } \\
\text { (ISP medium 7) }\end{array}$ & Moderate & White (a) & Bamboo (2gc) & None \\
\hline Nutrient agar & Moderate & None & Cinnamon (3le) & None \\
\hline Bennett agar & Good & None & $\begin{array}{l}\text { Pastel orange (4ic) to } \\
\text { light brown ( } 31 \mathrm{lg})\end{array}$ & None \\
\hline
\end{tabular}

* The color scheme used was Color Harmony Manual, 4th Ed., Container Corporation of America, Chicago, 1958.

white, yellow or red color series of TRESNER and BACKUs. ${ }^{52}$ The reverse side of colonies varied from pale yellow to orange depending on the medium. This orange color was somewhat $\mathrm{pH}$ sensitive, changing from orange to reddish with addition of $0.05 \mathrm{~N} \mathrm{NaOH}$ and from orange to yellowish with addition of $0.05 \mathrm{~N} \mathrm{HCl}$. Light brownish orange, water-soluble pigment was occasionally produced. 
Table 2. Comparison of strain SF2415 with related Streptomyces species.

\begin{tabular}{cccc}
\hline & $\begin{array}{c}\text { Strain } \\
\text { SF2415 }\end{array}$ & $\begin{array}{c}\text { Streptomyces } \\
\text { arabicus }\end{array}$ & $\begin{array}{c}\text { Streptomyces } \\
\text { erythrogriseus }\end{array}$ \\
\hline Aerial mass color on & $\mathrm{R}, \mathrm{W}$ & $\mathrm{Gy}$ & $\mathrm{Gy}$ \\
$\begin{array}{c}\text { ISP medium } 4 \\
\text { ISP medium 5 }\end{array}$ & $\mathrm{W}$ & $\mathrm{R}$ & $\mathrm{Gy}, \mathrm{R}, \mathrm{W}$ \\
$\begin{array}{c}\text { Utilization of } \\
\text { i-inositol }\end{array}$ & - & + & + \\
sucrose & - & \pm & - \\
raffinose & + & - & - \\
\hline
\end{tabular}

Abbreviations: R; Red, W; white, Gy; gray.

Symbols: +; Positive, 土; doubtful, -; negative.

Strain SF2415 grew within a temperature range of $15^{\circ} \mathrm{C}$ to $37^{\circ} \mathrm{C}$, with an optimum range of $26^{\circ} \mathrm{C}$ to $30^{\circ} \mathrm{C}$. Hydrolysis of starch and liquefaction of gelatin were positive. Reduction of nitrate, peptonization and coagulation of milk, and formation of melanoid pigment were all negative. Strain SF2415 tolerated $3 \% \mathrm{NaCl}$, but no growth occurred on more than $4 \% \mathrm{NaCl}$. On ISP medium 9 the strain utilized D-glucose, Dfructose, D-xylose, L-arabinose, D-mannitol, raffinose and L-rhamnose, but did not utilized $i$ inositol and sucrose.

LL-Diamino-pimeric acid was detected in whole-cell hydrolysates of the culture.

Based on the taxonomic properties described above, strain SF2415 is considered to belong to the genus Streptomyces. A comparison of the description of strain SF2415 with those of the Streptomyces species described previously showed

Fig. 3. Time course of fermentation in a 50-liter jar fermentor.

$\mathrm{O}$; Growth, $\bullet$ potency, $\triangle ; \mathrm{pH}$.
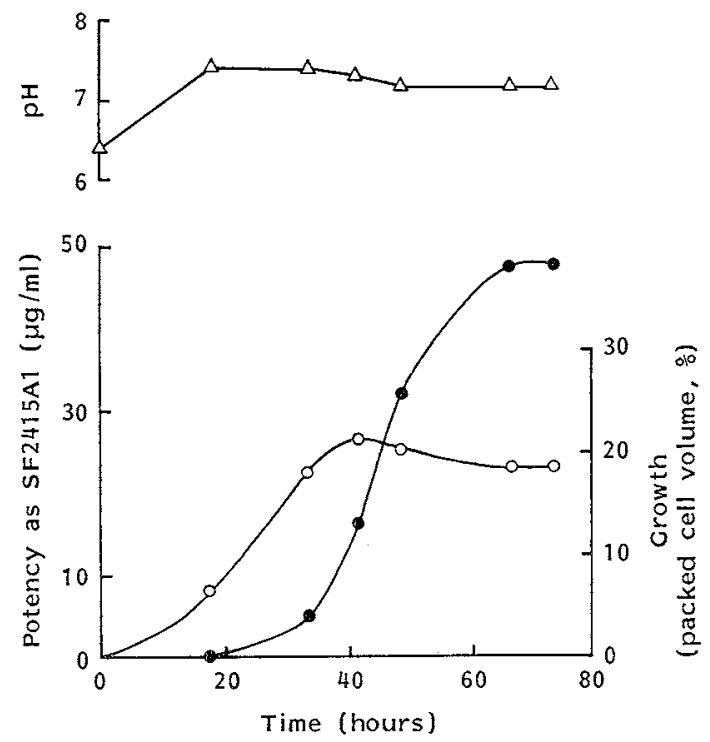
that no known species are identical to strain SF2415 based on the following combination of criteria: White, yellow or red color series, spiral spore chain, warty to spiny spore surface, non-chromogenic reaction on ISP media 1, 6 and 7, and carbon utilization pattern. Organisms that resemble this strain are Streptomyces arabicus $\left.{ }^{6}\right)$ and Streptomyces erythrogriseus. ${ }^{7)}$ As summarized in Table 2, however, strain SF2415 differs clearly from these two species in their aerial mass color and utilization of some carbon sources, such as $i$-inositol, sucrose and raffinose.

Therefore, we regard strain SF2415 as a new species, for which we propose the name Streptomyces aculeolatus (acu.le.o.la'tus. L. adj. aculeolatus somewhat spiny, referring to the spore surfaces). Strain SF2415, the type strain of $S$. aculeolatus, have been deposited in the Japan Collection of Microorganisms, with accession number of JCM 6055.

\section{Fermentation of $S$. aculeolatus}

The time course of antibiotics SF2415 fermentation in a 50-liter jar fermentor is shown in Fig. 3. 
Table 3. Physico-chemical properties of SF2415.

\begin{tabular}{|c|c|c|c|c|c|c|}
\hline & A1 & $\mathrm{A} 2$ & A3 & $\mathrm{B} 1$ & $\mathrm{~B} 2$ & B3 \\
\hline Appearance & Yellow needles & Red oil & Red powder & Pale yellow oil & Yellow oil & Yellow needles \\
\hline Molecular formula & $\mathrm{C}_{28} \mathrm{H}_{31} \mathrm{~N}_{2} \mathrm{O}_{5} \mathrm{Cl}$ & $\mathrm{C}_{26} \mathrm{H}_{30} \mathrm{~N}_{2} \mathrm{O}_{5}$ & $\mathrm{C}_{26} \mathrm{H}_{30} \mathrm{~N}_{2} \mathrm{O}_{5} \mathrm{Cl}_{2}$ & $\mathrm{C}_{26} \mathrm{H}_{33} \mathrm{O}_{5} \mathrm{Cl}$ & $\mathrm{C}_{26} \mathrm{H}_{32} \mathrm{O}_{5}$ & $\mathrm{C}_{26} \mathrm{H}_{32} \mathrm{O}_{5} \mathrm{Cl}_{2}$ \\
\hline FD-MS $(m / z)$ & $486,487,488$ & 450 & $521,523,524$ & $460,461,462$ & 424 & $494,495,496$ \\
\hline SI-MS $(m / z)$ & $487,488,489$ & 451 & & & 425 & \\
\hline HR-MS Caled & & & & 460.2015 & $424(\mathrm{EI})$ & $459.1936(\mathrm{M}-\mathrm{Cl})^{+}$ \\
\hline Found & & & & 460.2055 & & 459.1900 \\
\hline Anal Calcd & $\begin{array}{lr}\mathrm{C} & 64.12, \\
\mathrm{H} & 6.42, \\
\mathrm{~N} & 5.75, \\
\mathrm{C} 1 & 7.29\end{array}$ & $\begin{array}{ll}\text { C } & 69.31 \\
H & 6.71 \\
N & 6.22\end{array}$ & $\begin{array}{lr}\mathrm{C} & 59.89 \\
\mathrm{H} & 5.80 \\
\mathrm{~N} & 5.37 \\
\mathrm{C} & 13.60\end{array}$ & $\begin{array}{cc}\text { C } & 67.73 \\
\text { H } & 7.21 \\
\text { Cl } & 7.70\end{array}$ & $\begin{array}{l}\text { C } 73.56 \text {, } \\
\text { H } 7.60\end{array}$ & $\begin{array}{lr}\text { C } & 63.03 \\
\mathrm{H} & 6.51 \\
\mathrm{Cl} & 14.31\end{array}$ \\
\hline Found & $\begin{array}{lr}\mathrm{C} & 64.39 \\
\mathrm{H} & 6.53, \\
\mathrm{~N} & 5.54 \\
\mathrm{Cl} & 7.44\end{array}$ & $\begin{array}{l}\text { C } 69.09 \\
\mathrm{H}\end{array}$ & $\begin{array}{lr}\mathrm{C} & 59.20 \\
\mathrm{H} & 5.62, \\
\mathrm{~N} & 5.23, \\
\mathrm{Cl} & 13.36\end{array}$ & $\begin{array}{lr}\mathrm{C} & 67.15 \\
\mathrm{H} & 7.24, \\
\mathrm{Cl} & 7.06\end{array}$ & $\begin{array}{l}\text { C } 72.63 \text {, } \\
\text { H } 7.58\end{array}$ & $\begin{array}{lr}\text { C } & 63.56 \\
\text { H } & 6.80 \\
\text { Cl } & 14.48\end{array}$ \\
\hline$[\alpha]_{\mathrm{D}}^{22}(c 0.5, \mathrm{MeOH})$ & $+133^{\circ}$ & $+49^{\circ}$ & $+195^{\circ}$ & $-82^{\circ}$ & $+122^{\circ}$ & $+33^{\circ}$ \\
\hline $\mathrm{UV} \lambda_{\max }^{\mathrm{MeOH}} \mathrm{nm}(\varepsilon)$ & $\begin{array}{l}204(20,500), \\
254(19,200), \\
299(19,900), \\
364(5,500), \\
440(3,900)\end{array}$ & $\begin{array}{l}203(19,900), \\
232(14,400, \mathrm{sh}), \\
256(16,500), \\
308(11,900), \\
371(4,200), \\
453(2,800)\end{array}$ & $\begin{array}{l}204(19,500), \\
240(16,900, \mathrm{sh}), \\
254(18,300), \\
302(18,900), \\
376(4,900), \\
450(3,800)\end{array}$ & $\begin{array}{l}204(20,200), \\
260(20,300), \\
313(7,800), \\
347(7,100)\end{array}$ & $\begin{array}{l}205(23,900), \\
263(22,600), \\
360(7,400)\end{array}$ & $\begin{array}{l}205(21,400) \\
266(20,900) \\
327(7,800) \\
360(7,400)\end{array}$ \\
\hline$\lambda_{\max }^{\mathrm{MeOH}-\mathrm{HOI}} \mathrm{nm}(\varepsilon)$ & $\begin{array}{l}203(15,300), \\
253(19,200), \\
299(20,800), \\
366(5,500), \\
437(4,100)\end{array}$ & $\begin{array}{l}204(13,200), \\
235(13,100, \text { sh }) \\
255(15,600), \\
308(11,500), \\
371(3,600) \\
452(2,500)\end{array}$ & $\begin{array}{l}204(14,900), \\
240(17,500, \text { sh), } \\
252(18,400), \\
301(19,200), \\
375(5,200), \\
442(3,800)\end{array}$ & $\begin{array}{l}204(16,000), \\
260(21,000), \\
323(7,700), \\
345(7,200, \text { sh })\end{array}$ & $\begin{array}{l}205(20,700), \\
264(23,100), \\
361(7,600)\end{array}$ & $\begin{array}{l}205(16,600), \\
267(21,600), \\
332(7,900), \\
356(7,600)\end{array}$ \\
\hline $\operatorname{IR}\left(\mathrm{cm}^{-1}\right)$ & $\begin{array}{l}2155,1690,1645 \\
1600\end{array}$ & $\begin{array}{l}2150,1685,1640 \\
1605\end{array}$ & $\begin{array}{l}2160,2140,1690 \\
1650,1615\end{array}$ & $1690,1630,1600$ & $1680,1630,1600$ & $1685,1640,1600$ \\
\hline
\end{tabular}

FD-MS; Field desorption mass spectra, SI-MS; secondary ion mass spectra, HR-MS; high resolution mass spectra, EI; electron impact. 
The production of antibiotics was maximum at 65 hours after inoculation, reaching $48 \mu \mathrm{g} / \mathrm{ml}$ estimated as the antibiotic SF2415A1.

\section{Physico-chemical Properties of Antibiotics SF2415}

The physico-chemical properties of antibiotics SF2415A1, A2, A3, B1, B2 and B3 are listed in Table 3. UV spectra were measured on a Shimadzu UV-260 spectrophotometer. IR spectra were recorded on a Hitachi 260-10 infrared spectrophotometer. MS spectra were measured on a Hitachi M-80B mass spectrometer. Optical rotations were measured with a Perkin Elmer model 141 polari-

Fig. 4. UV spectrum of SF2415A1 in $\mathrm{MeOH}(20 \mu \mathrm{g} / \mathrm{ml})$.

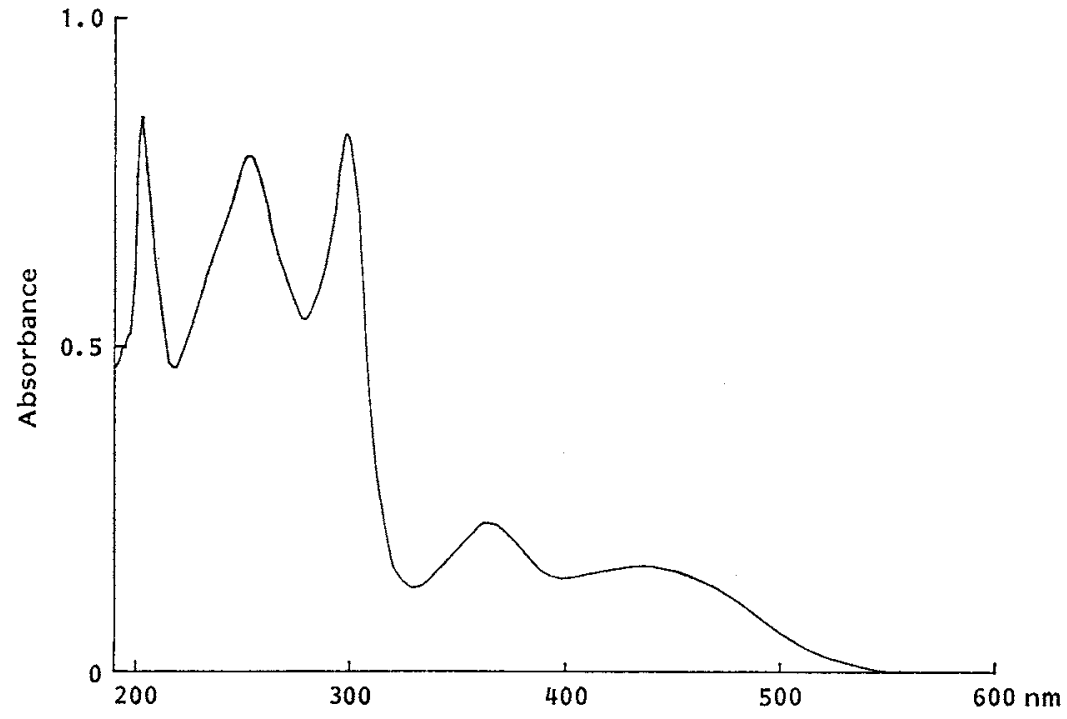

Fig. 5. IR spectrum of SF2415A1 (KBr).

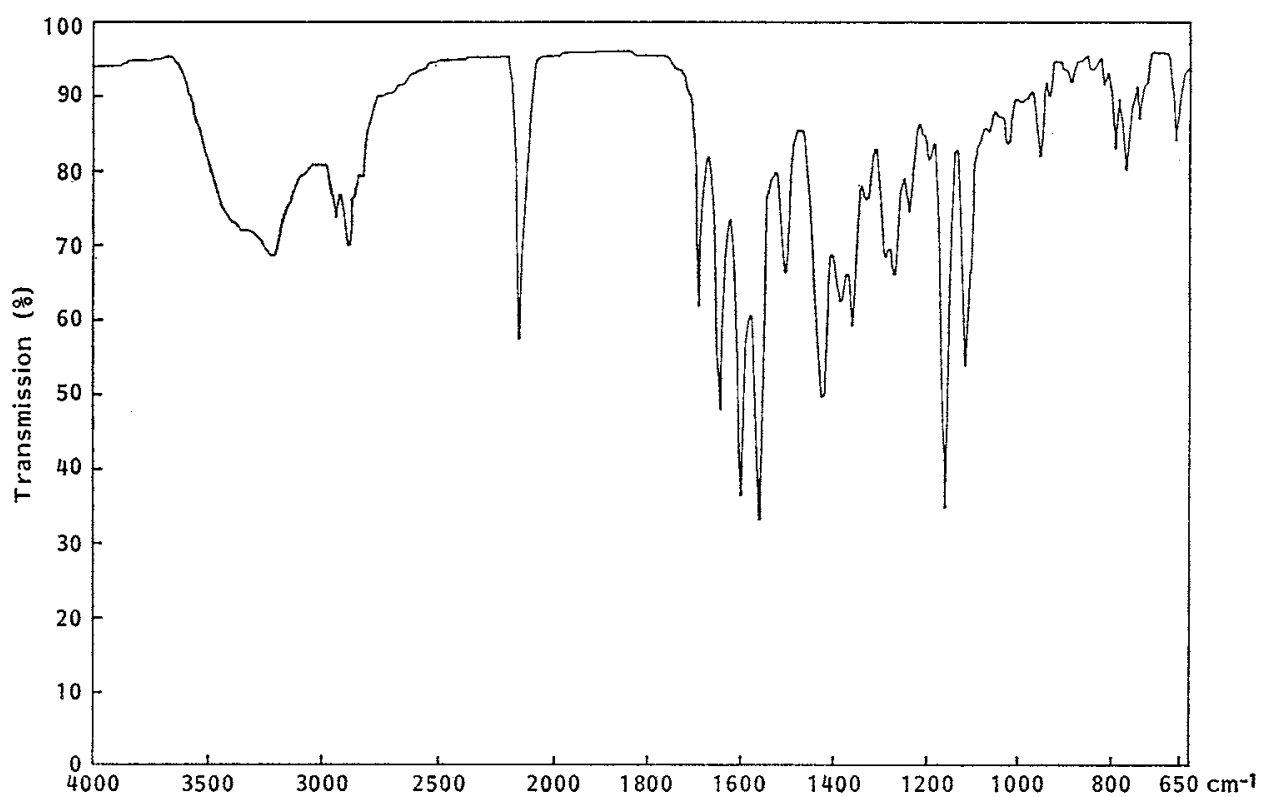


Fig. 6. ${ }^{1} \mathrm{H}$ NMR spectrum of $\mathrm{SF} 2415 \mathrm{Al}$ in $\mathrm{CDCl}_{3}(400 \mathrm{MHz})$.

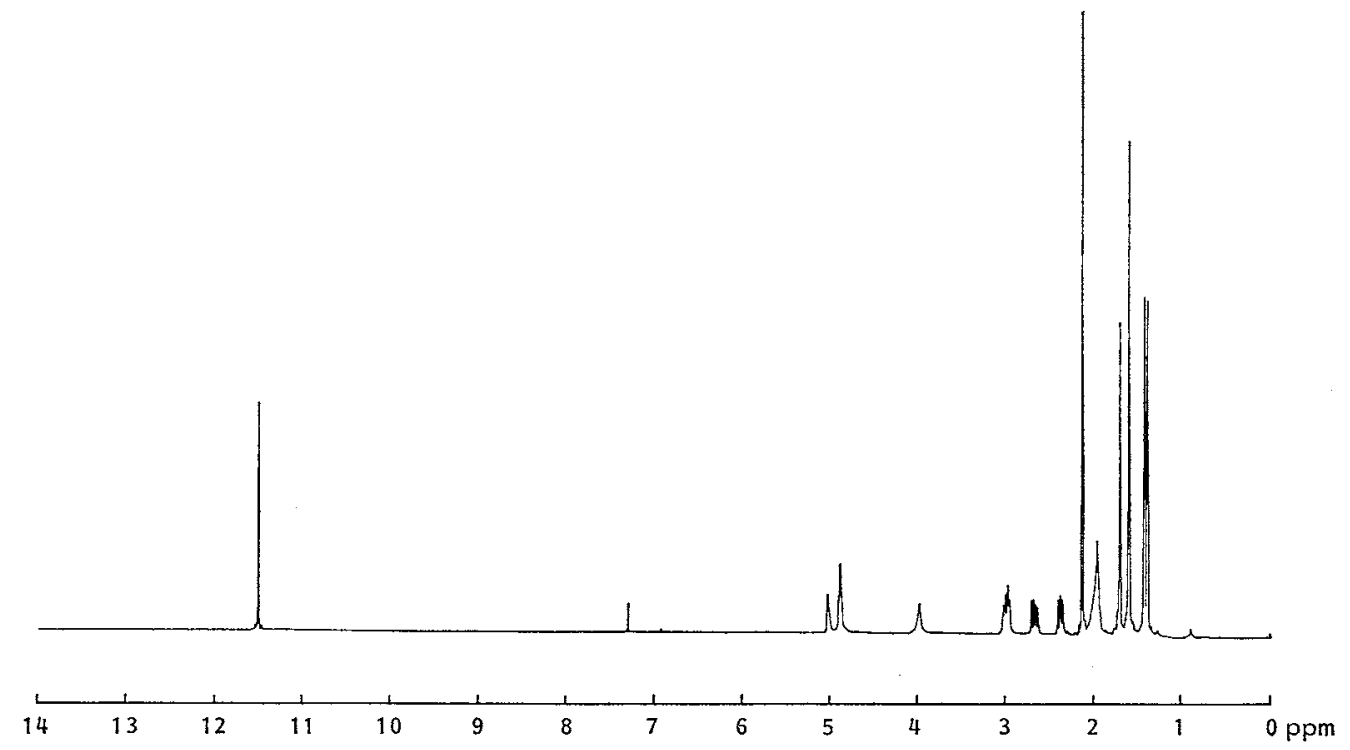

Fig. 7. ${ }^{13} \mathrm{C} \mathrm{NMR}$ spectrum of SF2415A1 in $\mathrm{CDCl}_{3}(100 \mathrm{MHz})$.

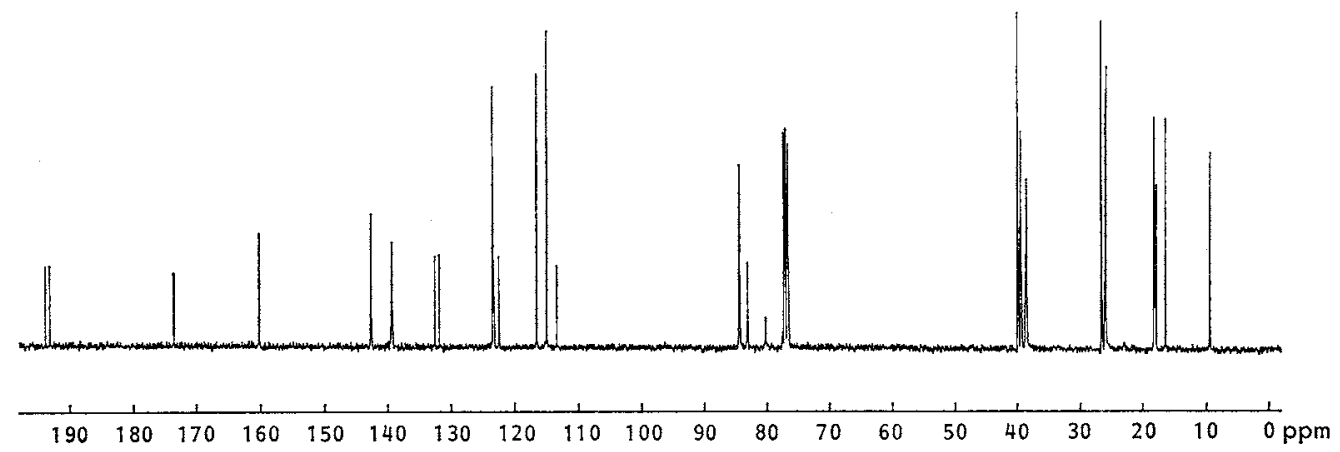

meter. Antibiotics SF2415 are soluble in organic solvents including methanol, chloroform, ethyl acetate and acetone, but almost insoluble in water. They show reddish purple colors with magnesium acetate in methanol and positive color reactions with $\mathrm{H}_{2} \mathrm{SO}_{4}, \mathrm{KMnO}_{4}$ and $\mathrm{NaMoO}_{4}$ reagents and negative with ninhydrin reaction. A1 showed melting point at $89 \sim 90^{\circ} \mathrm{C}$. Melting points of A3 and $\mathrm{B} 3$ could not be measured because of their hygroscopicities. IR spectra of A1, A3 and B3 were measured using $\mathrm{KBr}$ pellets and those of other SF2415 antibiotics were measured on $\mathrm{NaCl}$ plates. ${ }^{1} \mathrm{H}$ and ${ }^{13} \mathrm{C}$ NMR spectra were recorded on a Jeol JNM-GX400 spectrometer. The chemical shifts in $\mathrm{CDCl}_{3}$ refer to an internal standard of tetramethylsilane $(0 \mathrm{ppm})$. UV, IR, ${ }^{1} \mathrm{H}$ and ${ }^{13} \mathrm{C} \mathrm{NMR}$ spectra of A1 are shown in Figs. 4, 5, 6 and 7, respectively. Antibiotics SF2415 have the novel seminaphthoquinone structure, especially $\mathrm{A} 1, \mathrm{~A} 2$ and $\mathrm{A} 3$ have additional unique $\alpha$-diazoketone structure for natural products. Structural elucidation of antibiotics SF2415 will be reported in the next paper. ${ }^{1)}$

\section{Biological Activities of Antibiotics SF2415}

Antibiotics SF2415 have moderate activities against Gram-positive bacteria, but are not active against Gram-negative bacteria including Escherichia coli JC-2, E. coli No. 29, E. coli W3630 RGN823, 
Table 4. Antimicrobial activities of SF2415.

\begin{tabular}{lcccccc}
\hline \multirow{2}{*}{ Test organisms } & \multicolumn{7}{c}{ MIC $(\mu \mathrm{g} / \mathrm{m} 1)$} \\
\cline { 2 - 7 } & A1 & A2 & A3 & B1 & B2 & B3 \\
\hline Staphylococcus aureus 209-P JC-1 & 3.13 & 3.13 & 0.78 & 1.56 & 6.25 & 1.56 \\
S. aureus No. 26 & 3.13 & 3.13 & 0.78 & 3.13 & 6.25 & 1.56 \\
S. epidermidis ATCC 14990 & 3.13 & 3.13 & 0.78 & 3.13 & 6.25 & 3.13 \\
S. epidermidis 109 & 6.25 & 6.25 & 3.13 & 3.13 & 50 & 3.13 \\
Enterococcus faecalis ATCC 8043 & 12.5 & 6.25 & 6.25 & 6.25 & 6.25 & 6.25 \\
Bacillus anthracis No. 119 & 0.10 & $\mathbf{0 . 7 8}$ & 0.20 & 1.56 & 6.25 & 1.56 \\
\hline
\end{tabular}

E. coli JR66/W677, Citrobacter freundii GN346, Salmonella typhi 0-901-W, S. enteritidis No. 11, $S$. typhimurium LT-2, Salmonella sp. D-0001, Shigella sonnei EW33 Type 1, Klebsiella pneumoniae PCI 602, K. pneumoniae 22 \$3038, Proteus vulgaris OX19, P. mirabilis GN310, Providencia rettgeri J-0026, Morganella morganii Kono, Serratia marcescens MB-3848, Pseudomonas aeruginosa MB-3829, $P$. cepacia M-0527 and Xanthomonas maltophilia M-0627 at concentrations of $100 \mu \mathrm{g} / \mathrm{ml}$. The antibacterial activities of antibiotics SF2415 are shown in Table 4. When tested in mice by intraperitoneal administration, $A 1, A 2$ and $A 3$ were found to have $L D_{50}$ of less than $15 \mathrm{mg} / \mathrm{kg}$ and $L D_{50}$ of $B 1, B 2$ and $\mathrm{B} 3$ were $141,>200$ and $>100 \mathrm{mg} / \mathrm{kg}$, respectively.

\section{Acknowledgment}

The authors deeply thank to Dr. SHINICHI Kondo for his kind advice and his critical review of this manuscript.

\section{References}

1) Gomi, S.; S. Ohuchi, T. Sasaki, J. Itoh \& M. Sezaki: Studies on new antibiotics SF2415. II. The structural elucidation. J. Antibiotics 40: 740 749, 1987

2) Shirling, E. B. \& D. Gottlieb: Methods for characterization of Streptomyces species. Int. J. Syst. Bacteriol. 16: 313 340, 1966

3) Waksman, S. A. (Ed.): The Actinomycetes. Vol. 2. Classification, Identification and Description of Genera and Species. Williams \& Wilkins Co., Baltimore, 1961

4) Becker, B.; M. P. Lechevalier, R. E. Gordon \& H. A. Lechevalier: Rapid differentiation between Nocardia and Streptomyces by paper chromatography of whole-cell hydrolysates. Appl. Microbiol. 12: $421 \sim 423,1964$

5) Tresner, H. D. \& E. J. Backus: System of color wheels for streptomycete taxonomy. Appl. Microbiol. 11: 335 338, 1963

6) ShrReING, E. B. \& D. Gotrlieb: Cooperative description of type cultures of Streptomyces. Irr. Additional species descriptions from first and second studies. Int. J. Syst. Bacteriol. 18: 279 392, 1968

7) Shirling, E. B. \& D. Gottlieb: Cooperative description of type cultures of Streptomyces. V. Additional descriptions. Int. J. Syst. Bacteriol. 22: 265 394, 1972 